value and present excellent condition of the collections are the result of his faithful and disinterested work. Recently the department has been placed in charge of $\mathrm{Mr}$. Samuel Henshaw.

In a "partial catalogue" of the animals of Iowa published by the Iowa Agricultural College, Prof. H. Osborn enumerates 183 species of Ichneumonidae, Cynipidae and Tenthredinidae, 80 butterflies, 357 moths and I255 Coleoptera.

Some interesting observations on the habits of the young of mole-crickets are given by Dr. E. W. Doran in Science for Oct. I4. Among other things he finds that previous to their first moult they can jump to the distance of five or six inches.

The notes and figures of Myriapoda left by the late A. Humbert are to be published shortly by the Société de physique et d'histoire naturelle of Geneva under the supervision of Dr. H. de Saussure. The text is rather meagre but the figures are valuable and finely executed.

\section{PROCEEDINGS OF SOCIETIES.}

\section{CAMBRIDGE ENTOMOLOGICAL CLUB.}

I4 October, I892. - The I 72 d meeting was held at ${ }_{5} 66$ Brattle Street. Mr. S. H. Scudder was chosen chairman and Mr. A. P. Morse secretary pro tem.

Mr. S. H. Scudder reported the capture of Anthomaster leonardus near Gardiner, Me., further east than it was before known; the female was seen laying eggs Aug. 29th on Agrostis scabra; these hatched in about 20 days, but the larvae refused ordinary grasses, and as they were as plump when a month old as when born, it seemed probable that their habit was to hibernate without first feeding.

Mr. S. Henshaw reported Callidryas eubule as not uncommon this year on Nantucket in the latter part of September.

\title{
The Butterflies of the Eastern United States and Canada.
}

With special reference to New England. By Samuel H. Scudder.

Illustrated with 96 plates of Butterflies, Caterpillars, Chrysalids, etc. (of which $4 \mathrm{I}$ are colored) which include about 2,000 Figures besides Maps and Portraits. I958 Pages of Text.

Vol. I. Introduction; Nymphalidae.

Vol. 2. Remaining Families of Butterflies.

Vol. 3. Appendix, Plates and Index.

The set, 3 vols., royal 8vo, half levant, $\$ 75.00$ net.

\section{HOUGHTON, MIFFLIN \& CO., 4 Park St., Boston, Mass.}

\section{RHOPALOCERA.}

Rhopalocera from Europe, New Grenada, Sikkim, Assam, Pulo Nias, British Guiana, Congo Free State and various Polynesian Islands. Correspondents will oblige by stating desiderata. No post cards.

DR. J. T. T. REED, Ryhope, Sunderland, England.

ADVERTISEMENT.

Undersigned wishes to obtain either by exchange or for cash, Cicindelidae and rare Carabidae from all parts of the U.S. Lists please address to

A. Luetgens, „o7 E. I5 Street, N. Y. City.
THE NEW ENGLAND SPIDERS.

By J. H. EMERTON.

In seven parts from the Transactions of the Connecticut Academy of Arts and Sciences Vols. VI, VII and VIII containing descriptions of 340 species with I400 figures.

Price for the whole $\$ 6.00$, or either part sold separately. Sent by mail on receipt of price.

\section{J. H. EMERTON,}

Boston, Mass. 

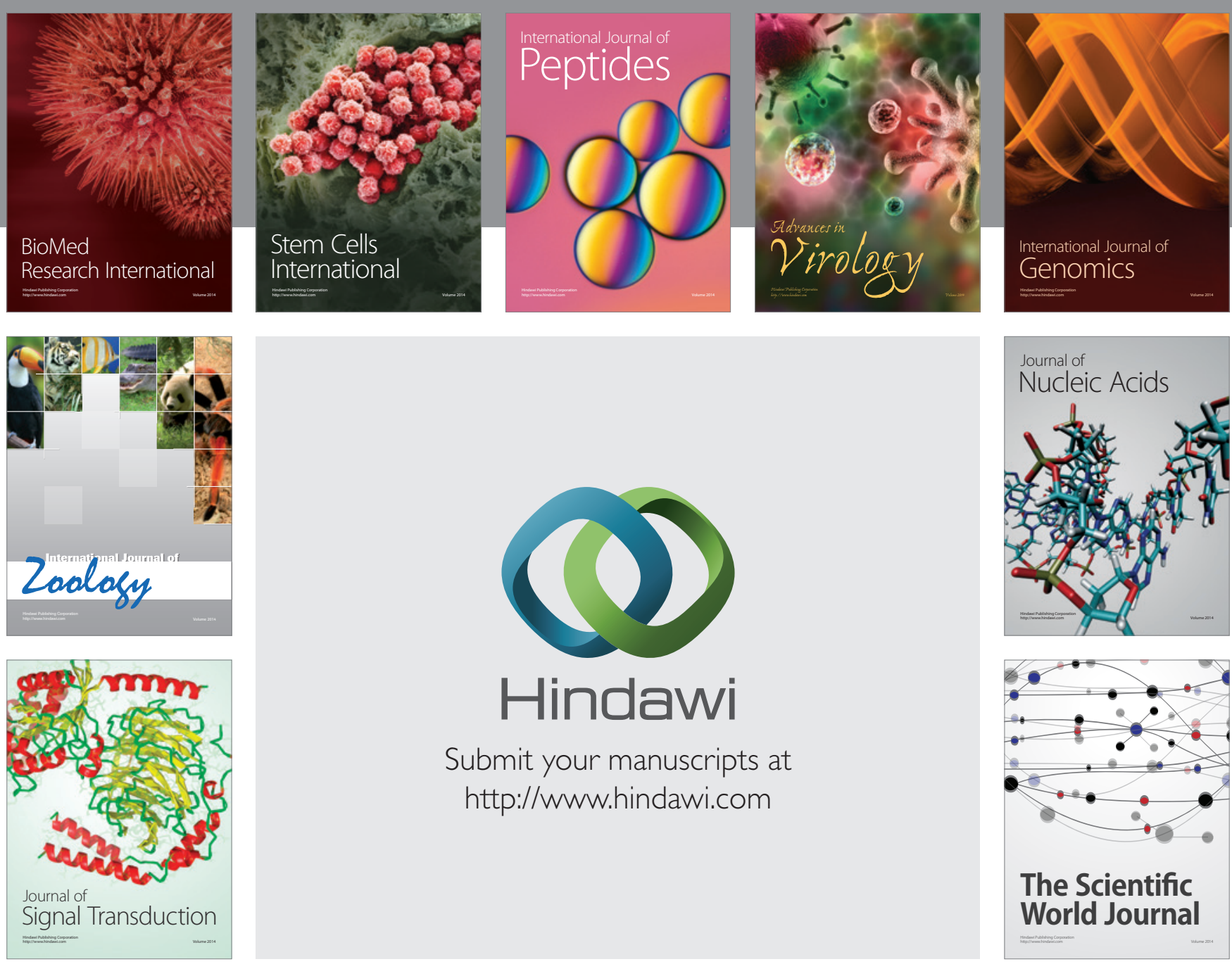

Submit your manuscripts at

http://www.hindawi.com
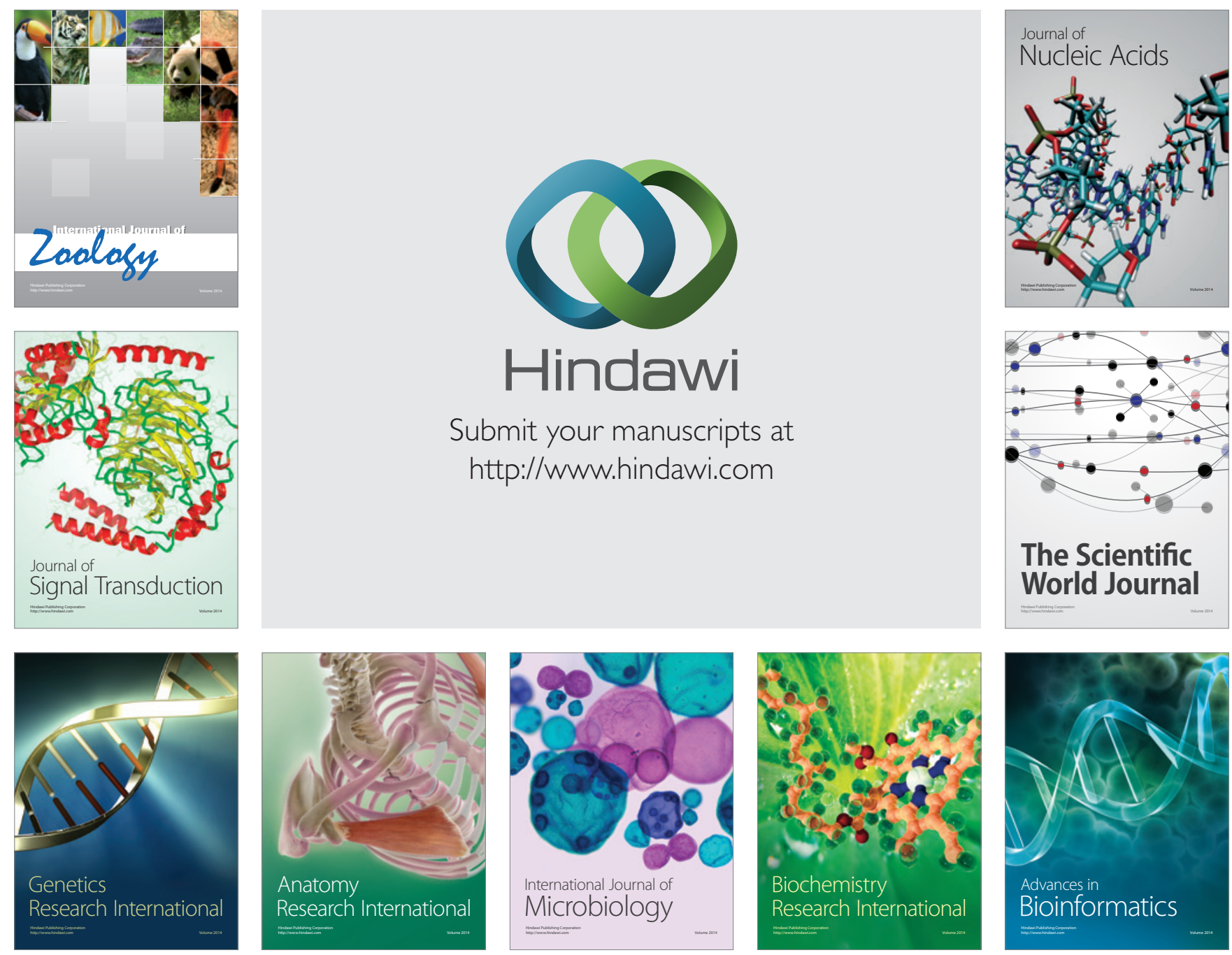

The Scientific World Journal
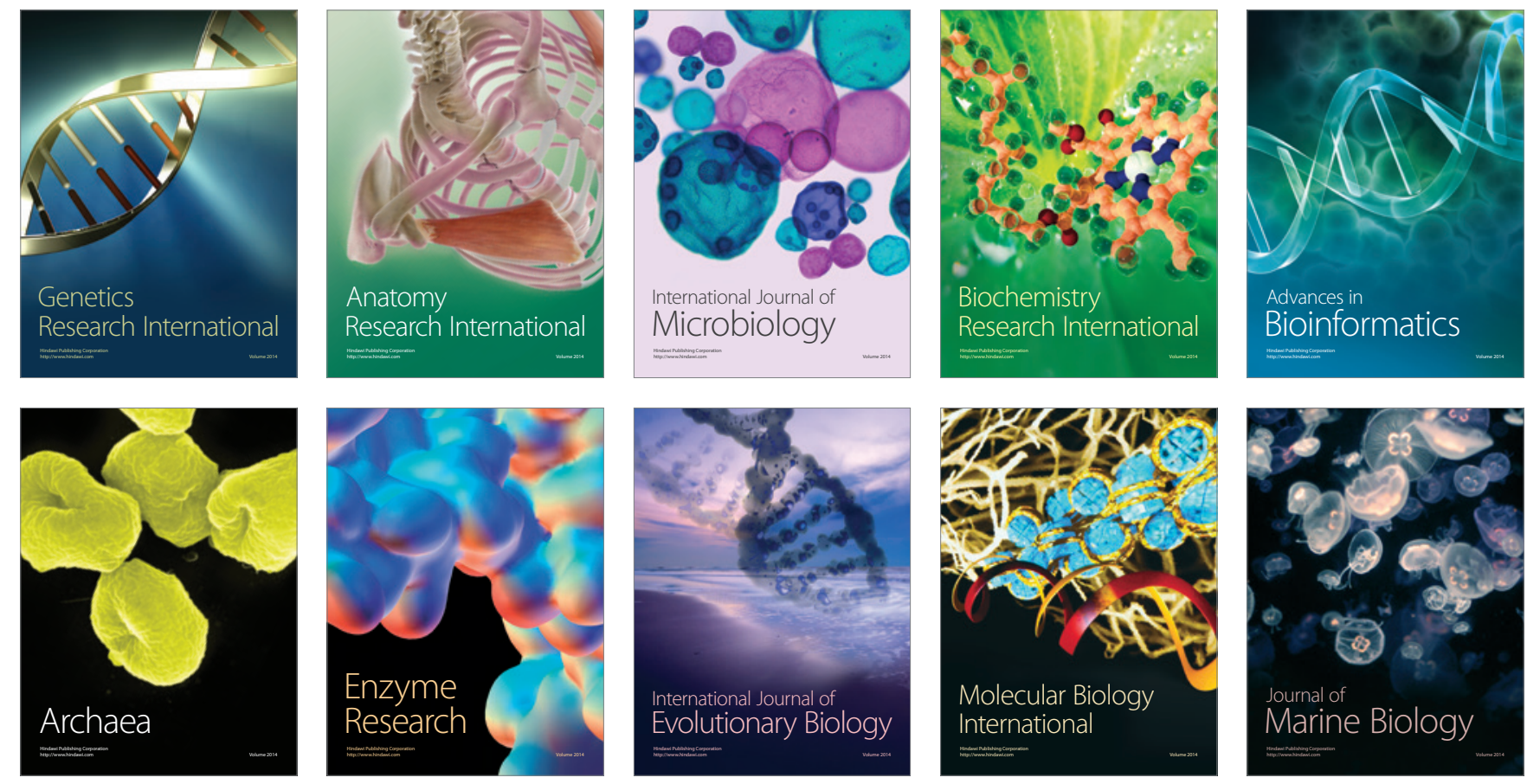